\title{
A Petrological Approach to find the Source Location of Raw Materials for Prehistoric Stone Axes
}

\author{
Hirokazu Maekawa ${ }^{1 *}$ and Kazuyoshi Ohtsuka ${ }^{2}$ \\ ${ }^{1}$ Professor Emeritus, Osaka Prefecture University, Japan \\ ${ }^{2}$ Professor Emeritus, National Museum of Ethnology, Japan
}

*Corresponding author: Hirokazu Maekawa, Organization of Research Promotion,

Osaka Prefecture University, Osaka, 599-8531, Japan

Received Date: September 02, 2021

Published Date: September 21, 2021

\begin{abstract}
Numerous green polished stone axes were excavated from the Sannai-Maruyama site of the Jomon period (5.9-4.2 cal kyr BP). The axes exhibited unique petrological characteristics; therefore, we successfully identified the minimal locality of the source rock used to make these axes. Our study presents an example of a petrological approach for the archaeological studies of stone axes.
\end{abstract}

Keywords: Sannai-Maruyama site; Jomon Period; Stone ax

\section{Introduction}

Many green polished stone axes have been excavated from the Sannai-Maruyama site, which is a large mid-Holocene (5.9 to $4.2 \mathrm{cal}$ kyr BP) archaeological site in Japan. Maekawa et al. [1] conducted a petrological study of the green polished stone axes and revealed that the outcrop of raw materials for stone axes was minimal and that the Jomon people had used them selectively. The origin of the stone ax has been rarely investigated, and thus, we outlined this manuscript as an example of the petrological approach for the archaeological studies on the stone axes and considered its significance.

\section{Unique Mineral Texture of Green Polished Stone Axes}

When we first cut the green polished stone ax with the cutting equipment, we were amazed at its hardness and tenacity and impressed by the Jomon people's search for this wonderful stone material to make the stone axes. The question was immediately answered through observing a thin section of the ax using a polarizing microscope, why the ax was so hard, and why it was tenacious. The axes were made of massive greenstones that originated from the weakly metamorphosed fine-grained volcaniclastic rock. They had a peculiar mineral texture that included numerous acicular actinolites growing in random directions within a hard matrix of fine-grained quartz and albite (Figure 1). As a first step in this study, we used this unique mineral texture as a reference to track the source of the stone ax. During our research based on the mineral texture, we investigated the green polished stone axes excavated from four different Jomon sites in southern Hokkaido. The stone axes with the mineral textures similar to those obtained from the Sannai-Maruyama site were found at all sites in southern Hokkaido. Therefore, it is considered that they were distributed widely to the Sannai-Maruyama and Jomon archaeological sites in southern Hokkaido.

\section{Aotora stone}

The residents of the Biratori town, southern Hokkaido, are aware that the "Aotora stone" was the possible primary raw material used to make the stone axes (e.g., [2]), which the residents valued as an ornament. The Aotora stone is a greenstone commonly found as cobble or boulder in the Nukabira River, running throughout the Biratori town. Seven Aotora stone samples were collected. The Aotora stone was found to have originated from the volcaniclastic rock and consisted alternating soft dark-green and hard pale-green 
layers 0.1 to $30 \mathrm{~mm}$ thickness (Figure 2). It often had a characteristic shape with uneven surface due to differential erosion. The palegreen layer was fine-grained and rich in quartz and albite, whereas the dark-green layer was composed of coarse-grained picritic detritus and contained abundant chlorite with low to absence in quartz and albite contents. The pale-green layer usually exhibits a metamorphic texture similar to that of the stone axes, whereas the dark-green layer often exhibits a primary epiclastic texture, and sometimes a hyaloclastic texture.

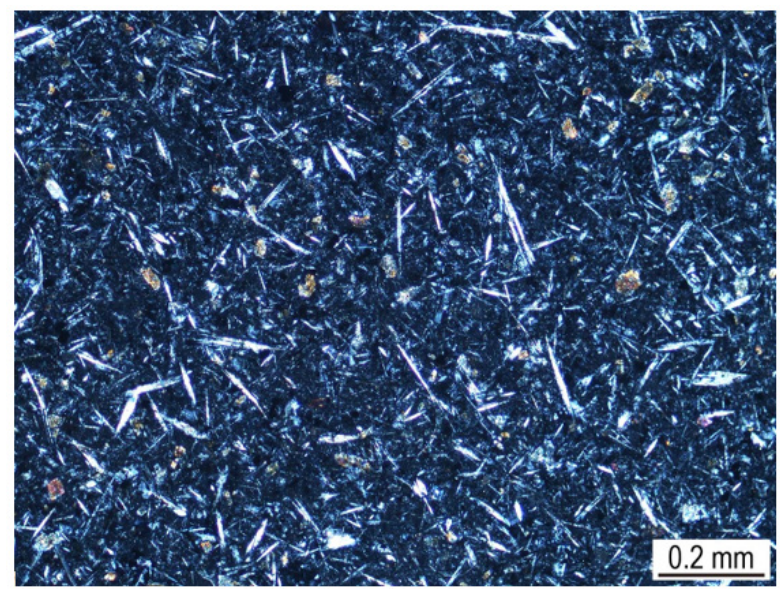

Figure 1: A photomicrograph of the green polished stone ax from the Sannai-Maruyama site. cross-polarized light. Acicular crystals are actinolite, granular ones are epidote, and dark matrix consists mainly of quartz and albite.

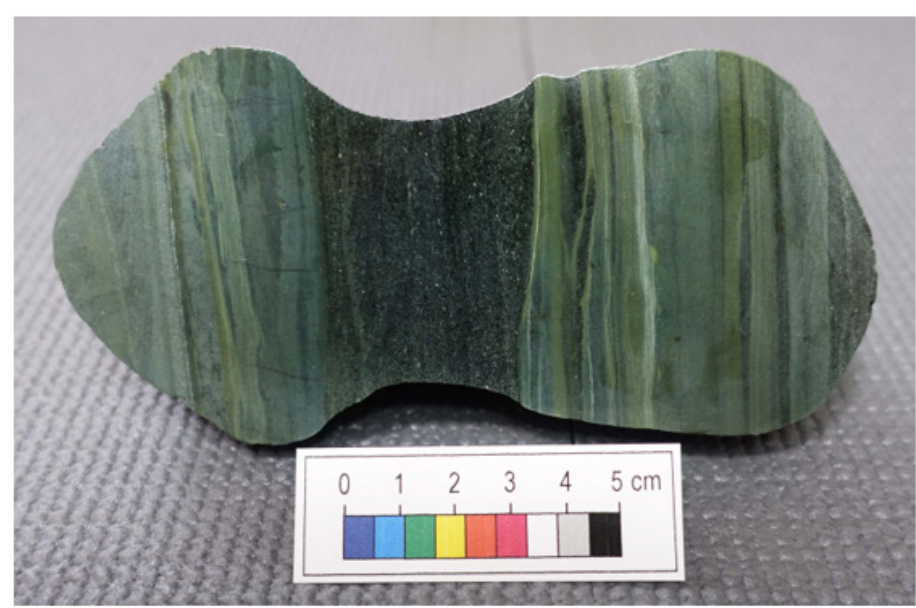

Figure 2: An Aotora stone collected at the dry riverbed near Toyonuka Bridge of the Nukabira River. A dark-green layer of picrite debris was identified in the center and a pale-green layer with fine lamination on both its sides.

\section{Greenstones in the Shidoni River area}

The residents of the Biratori town reported that the Aotora stone occurs in outcrops along the Shidoni River, a tributary of the Nukabira River. The area was underlain by greenstones, that is, weakly metamorphosed pillow and massive lavas, and associated volcaniclastic rocks, such as pillow breccias and hyaloclastites, with minor dolerite dykes. The composition of lavas was basic $\left(\mathrm{SiO}_{2}=49.10-50.77 \mathrm{wt} \%\right)$. Picrite and picritic breccia $\left(\mathrm{SiO}_{2}=41.53-\right.$ $46.24 \mathrm{wt} \%$ ) were also found in this area. Picrite was dark green to black in color and had shear fabrics, such as block-in-matrix fabrics, due to the chloritization of olivine. Picrite has been reported from the Kamuikotan belt and the Sorachi Group in the Sorachi-Yezo belt. Ichiyama et al. (2012) suggested that the picrite in this area originated from extremely high-temperature magma $\left(\sim 1700^{\circ} \mathrm{C}\right)$ and proposed that the magmatism was related to a hot mantle plume beneath an extensive oceanic large igneous province.

An outcrop occupied by volcaniclastic rocks with characteristics of the Aotora stone was found in the Shidoni River (Loc. 1 in Figure 8 of [1]). They were composed of alternate bands of pale-green layers with a texture similar to that of the stone axes and darkgreen layers of picrite detritus. The volcaniclastic rocks found near Loc. 1 frequently contain abundant picrite fragments. Although the volcaniclastic rocks without dark-green picritic layers were also found in the study area, they did not exhibit that unique texture. Therefore, picrite is essential to understand the origin of the Aotora stone. 


\section{Geochemistry}

The green polished stone axes had a relatively high $\mathrm{SiO}_{2}(=53.5-$ $56.8 \mathrm{wt} \%)$ and were found to be rich in $\mathrm{Cr}(=451-883 \mathrm{ppm})$ and $\mathrm{Ni}$ $(=248-432 \mathrm{ppm})$. It is concordant with the chemical characteristics of the pale-green layer of the Aotora stones and outcrop found at Loc. 1. Conversely, the dark-green layer of the Aotora stone and outcrop was found to be poor in $\mathrm{SiO}_{2}$ (45.7-51.3 wt\%), remarkably rich in $\mathrm{Cr}$ (=2624-3048 ppm) and $\mathrm{Ni}$ (=933-1266 ppm), and is very similar to picrite. Pillow and massive lavas and picrites obtained from the Shidoni River area were characterized by a light rare earth element (LREE) depleted pattern compared to heavy rare earth elements (HREEs) when normalized to CI-chondrite. The stone axes excavated from the Sannai-Maruyama site, Aotora stones, and pale-green layer at Loc. 1 showed LREE-enriched patterns with very low HREE. They exhibited Ce negative anomalies, and some were with negative or positive $\mathrm{Eu}$ anomalies, with $\mathrm{Eu} / \mathrm{Eu}^{*}$ values of 0.73-1.48. Although Aotora stones contained fewer total REEs than the stone axes and pale-green layer at Loc. 1, the pale-green layer at Loc. 1 had REE patterns similar to those of the stone axes obtained from the Sannai-Maruyama site. Since these rocks originated from the volcaniclastic rocks, it is likely possible that LREEs were added to these rocks because they are mobile in aqueous fluids (e.g., [4]).

\section{Discussion}

The greenstones along the Shidoni River were formerly considered to belong to the Sorachi Group of the Hidaka Supergroup [5]. However, recent studies suggested that they belong to the Iwashimizu Complex of the Kamuikotan blet in the Sorachi-Yezo blet (e.g., [6]). The study area mostly comprises basaltic lava and is very similar in lithology to the lower part of the Sorachi Group, so its attribution is still controversial. Maekawa et al. [1] did not discuss the attribution of greenstones, but both picritic and intermediate $\left(\mathrm{SiO}_{2}=61.8-63.1 \mathrm{wt} \%\right.$ [7]) volcanic activities were reported from the Sorachi Group. Considering the modes of occurrence of alternating layers of dark- and pale-green parts of the Aotora stone (Figure 2), it is highly probable that intermediate volcaniclastic materials and picrite debris from the Sorachi Group were supplied alternately in this area to form the volcaniclastic rock that is the source of the
Aotora stone. We did not succeed to find other outcrops of the volcaniclastic rock like Loc. 1 . Without a doubt, this is a very rare situation. It appears that it was convenient for the Jomon people to scrape off the relatively soft dark-green layer of the Aotora stone and fabricate stone axes from the remaining hard flat plate of the pale-green layer. It is surprising that the Jomon people selected very rare and useful raw rocks to make stone axes. The excavation of a large number of green polished stone axes at the Sannai-Maruyama site, which is far from the place of their origin, suggests that they were in high demand. We, therefore, consider that the stone axes made using Aotora stone were of sufficiently high quality as a tool to support the construction of buildings at that time.

\section{Acknowledgement}

None.

\section{Conflict of Interest}

No conflict of interest.

\section{References}

1. Maekawa H, Ohtsuka K, Yamamoto K, Gouchi N, Hattori K (2021) Petrology of green polished stone axes of the Jomon period from the Sannai-Maruyama site, Japan, investigating the origin of source rock. Island Arc 30: e12384.

2. Gouchi N (2004) The source locality of polished stone axes from the Sannai-Maruyama site. Reports of the Sannai-Maruyama Special Historical Site 7: 16-20.

3. Ichiyama Y, Ishiwatari A, Kimura J, Senda R, Kawabata H, Tatsumi Y (2012) Picrites in central Hokkaido: Evidence of extremely high temperature magmatism in the Late Jurassic Ocean recorded in an accreted oceanic plateau. Geology 40: 411-414.

4. Ludden N J, Thompson G (1979) An evaluation of the behavior of the rare earth elements during the weathering of sea-floor basalt. Earth and Planetary Science Letters 43: 85-92.

5. Suzuki M (1977) Characteristics of diabase and spilitic rocks in the axial region of Hokkaido and Genesis of spilite. Geological Survey of Hokkaido Special Report 49: 1-36.

6. Ueda H (2005) Accretion and exhumation structures formed by deeply subducted seamounts in the Kamuikotan high-pressure/temperature zone, Hokkaido, Japan. Tectonics, 24, TC2007, pp. 1-17.

7. Watanabe K, Niida K, (1987) Greenstones in the Nukabiragawa Area of the Kamuikotan Belt, Hokkaido. Earth Science 41: 151-164. 